\title{
The Relationship between Tourism and Socio-Economic Aspects of the Maasai in Ngorongoro Conservation, Tanzania
}

\author{
Asantael Williams Melita \\ Ngorongoro Conservation Area Authority \\ P. O. Box 1, Ngorongoro, Tanzania
}

Tel: 255-767-970-097_E-mail: asante_melita@yahoo.com

Received: May 23, 2014 Accepted: June 11, 2014 Published: June 24, 2014

doi:10.5296/bmh.v2i1.5860

URL: http://dx.doi.org/10.5296/bmh.v2i1.5860

\begin{abstract}
Tourism Industry by its nature in the World, it is the trait that cannot be separated from the social life of the communities as it is practised on their territorial lands that they depend for their socio-economic aspects. That strong relationship has caused rapid growth of tourism activities to developing countries and led to new national and international expectations for tourism as an agent of socio-economic development. The World GDP contributions from tourism by 2013 grew to $3.1 \%$ and contribute to 101 million jobs, and in Tanzania total contribution to GDP was $12.7 \%$ where by contributed $4.9 \%$ direct and total employment contribution were $11.2 \%$ and $3.8 \%$ direct of the total employment. In Ngorongoro Conservation Area with a population of about 87,851 residents from Maasai, Datoga and Hadzabe tourism contributed to $92 \%$ of the total economy of the area where by $8 \%$ was from other sources and $48 \%$ total community economy and $29.2 \%$ direct to people and $9.7 \%$ of total employment. The findings revealed that major relationship of the tourism and socio-economic based on economic activities contributions (livestock services), Social services (education, healthy, culture and life style), resources ownerships and infrastructure developments. The paper considered community survey of 120 local residents from 4 wards of the NCA, examines whether tourism has direct relationship to the Socio-economic aspects of the residents of the area and the levels of the contributions to their development. I found that regardless a claimed little contribution to their economy; many people appreciated the social and economic changes related to the tourism of the area.
\end{abstract}

Keywords: Tourism, Socio-economic indicators, Relationship, Community economy, Livestock economy, Economic changes 
Tourism has been a major factor of the economic changes of the society in the world. In other words, Tourism and Socio- economic aspects are the related activity pertains in most of the communities in the world. Basing on the studies that had been conducted in many parts of the world, tourism and social economic aspects of the communities are inseparable because of the nature and the way they depend each other in the places where they have interacted. Stronza (2001) stated that these two aspects are related because are happening in people's places. The study further explained that tourism occurs in most, if not all, human societies. It is, at least, safe to say that people in nearly every society have been touched in some way by tourism. There are some questions that most of the studies have been posed on tourism and its relationship with community's socio-economic aspects. Adams (1984), (1995); Bruner (1987); Bruner \& Kirshenblatt-Gimblett (1994); and Urry (1990) asked how culture is represented in tourist settings, and how is it perceived. This was similarly asked by Bendix (1989), Gamper (1981) and Leong (1989) that how are cultural traditions changed or reinvented over time to match tourist expectations. Furthermore, Mansperger (1995) and Seiler-Baldinger (1988) asked how indigenous societies change as they become integrated with the tourism market, Bookbinder et al. (1998), Wunder (1999) and Epler-Wood (1998) asked why local participation is relevant to the success of tourism. Melita et al. (2013) stated that tourism is complementing the communities' livelihood and revealed that society in the Ngorongoro Conservation area is supporting tourism as has identified it being an alternative of their declining livestock keeping economy. Tourism is naturally expending and growing to make it a big industry that is highly dependable by a lot of societies in the world. It has been happening in most of the parts of the world. Tourism has gained popularity in the economic growing, contribution to the nations GDP's and being that dynamic, tourism has recognised to be a significant catalyst of economic development and socio-political change, processes that are central to the interests of many people (Stronza, 2001).

The resident in the NCA during the area establishment in 1958/59 were 10,633 people and they were defined as nomads living within the Ngorongoro area. Being Nomads, means that, they were basically relying on pastorals' as the main economic activity and therefore their welfare were measured in terms of livestock holding (Runyoro, 2006). The NCAA was given among the core activities to safeguard the right interests of the indigenous residents of the area. By doing that most of the services were provided free and that encouraged many immigrants within the area. The Socio- Economic aspects of the communities in the area had a lot of challenges which interrupted social developments and change over the economic activities of the Maasai within the NCA. The livestock (especially cattle) keeping started declining in 1977 (Kurji, 1981) and that increased the thoughts that tourism could be the best alternative to complement to declining economy of the residents in the NCA. The small stocks maintained slightly increase up to 2007 and sharp increase in 2013 as was easy to keep and also easy to buy from the stocks markets. 


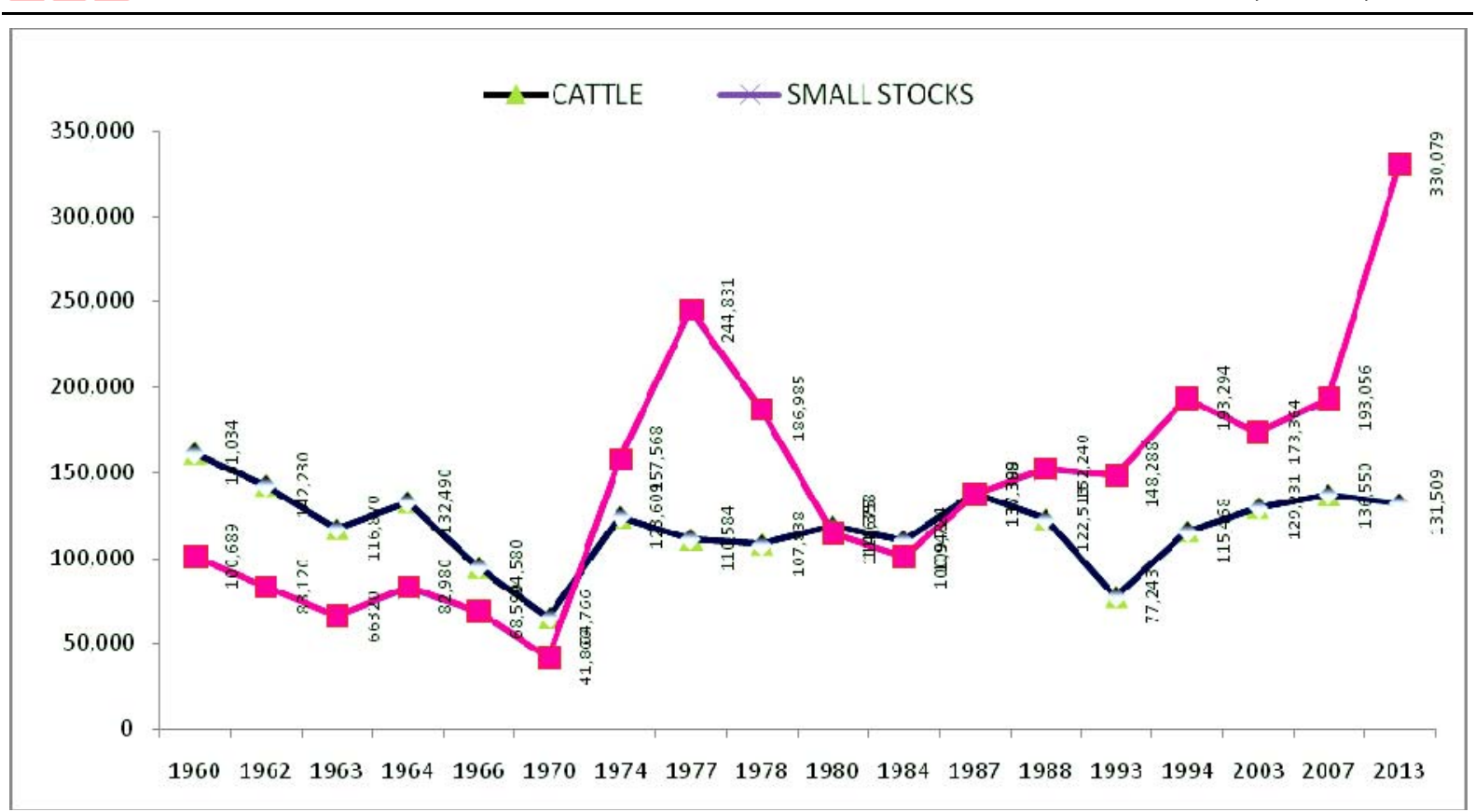

Figure 1. Livestock population trend in the NCA to 2013

The communities started being involved into tourism activities in 1991, when the first cultural Boma at Loongoku authorized and the other one at Nooseiya constructed to remove illegal cultural boma at Motony Sub Village in Oloirobi. The administration jurisdictions were given to the village council and the traditional leaders. The Bomas aimed to have several functions such as singing, dancing and selling handicrafts to tourists. Other activities were guiding tourists at the bomas, selling animals (milk, skins) and forest products (honey). While dancing and singing is the responsibility of genders, making and selling of artefacts' was mainly done by women (Melubo, 2007; Melita, 2009; Melita \& Mendlinger, 2013).

Melubo (2007), Runyoro (2006) and Melita (2009) reported that Lodges/Hotels also supported community development infrastructure and provide market for Maasai people local products. Also some other activities expected to boost the local economy was shared campsites that were established in the area in 2004. Generally the deeply community involvement and participation into Tourism in NCA increased the individuals economy but was commented to have competed the primary economic activities which is livestock keeping.

Currently the communities in the NCA have decided to reside permanently within the area and they are now conducting small scale business (Melita, 2009). All these businesses are basing on the tourism activities that are being conducted within the area. Dependence on tourism has declined the interest of the livestock keeping within the area. Currently the livestock human population ration is declined to 1:2 castles and 1:1.5 small stocks compare to 1:12 cattle's and 1:17 small stock in 1990's. Regardless the increased number of people in the area to 87,851 individuals, about $35,187(40.1 \%)$ of the population who are the good manpower to make the strong livestock economy they are not considering the Livestock 
keeping as potential economic activities. But if all of them were supporting livestock keeping the ratio (per capital) could be higher than the one recorded.

By looking on the socio- economic aspects of the residents within the Ngorongoro Conservation Area, tourism growing situation seems to have deviated and incline the interest of communities supporting their basic primary economic activities. Socio-economic of the communities' has been changed. This is related to a discussion by Lett (1989) when he argued that once credited tourism with bringing about the single largest peaceful movement of people across cultural boundaries in the history of the world can change the attitudes of people. The impact of tourism has gone further to changes of social life of the society within the NCA (Melubo, 2007; Melita \& Mendlinger, 2013) Nevertheless; Stronza (2001) argued that when tourists and locals come together, both have the opportunity not only to glimpse how others live, but also to reflect on their own lives through the eyes of others. As a result, these cross-cultural interactions often cue "live performances" of some of the broadest theoretical issues.

Basing on the life style change, economic benefits, social interaction between a host and guest, exchange of knowledge, business trading between the guest and host, this study has noted that there is a power in tourism that acts as a factor on the relationship between tourism and the socio-economic change of the society. This relationship was also observed by MacCannell (1976) when he proposed that by following in the footsteps of tourists, one can begin to understand the value systems of the modern world. His purpose suggesting that was to craft ethnography of modern society. However it was strongly suggested that the concern was characterized by the feelings of alienation, fragmentation, and superficiality (Stronza, 2007).

\section{Methodology}

Various methodologies were involved in this study where the details on the techniques was justified and proved the hypotheses. A research design and approach adapted to a survey design and a combination of quantitative and qualitative approach were involved. The study on population and sampling strategies used where the Samples from five Wards, selected from the 2013 census and run through Microsoft Excel Window 7-Pop Tools 3.06 for random sampling.

Data collection involved a combination of quantitative and qualitative approaches. The quantitative approach was adopted to collect data from the community members from five wards (Ngorongoro, Olbalbal, Nainokanoka, Endulen and Kakesio) by use of the questionnaires. Qualitative data were used to collect data from random samples in the same five Wards and from members of the Ngorongoro Pastoralist Council (NPC) by interviews. The combined approach was desired because it makes possible for qualitative to complement quantitative data and vice versa and increase the data validity and degree of confidence. 


\section{Macrothink}

\section{Results}

\subsection{The Conceptual Frame Work}

The conceptual framework for this study involves three sets of variables; independent variables, intervening variables and the dependent variable. The independent variables are the respondents involved in small scale businesses members in tourism project, association or council, owners/partnerships in any tour company, employment in Tour Company or NCAA and the NCAA contributions. The intervening variables include entrepreneurship culture among community members, institutional arrangements between NPC and NCAA and NCA policy framework. The dependent variable is community welfare, which is measured by amount of income that community earns per year and better access of the social services like health and education.

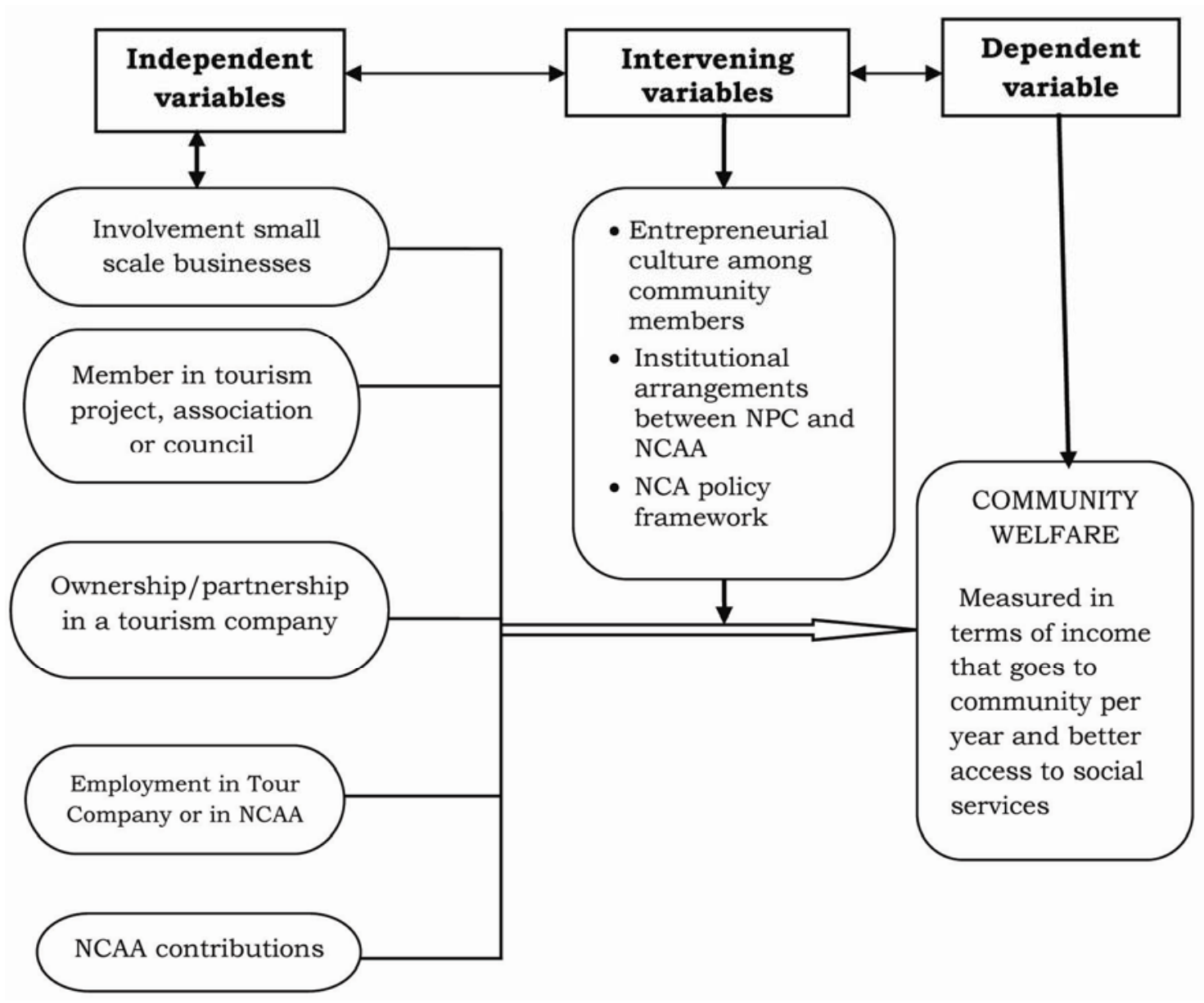

Figure 2. Relationship between independent, intervening and the dependent variable Source: Melita, 2014 


\section{Macrothink}

The quantitative survey included a total of 120 community members including $88(73.3 \%)$ males and $32(26.7 \%)$ females. The respondents were sampled from five wards where 37 (30.8\%) were from Ngorongoro, 16 (13.3\%) from Endulen, 13 (10.8\%) from Olbalbal, 34 $(28.3 \%)$ from Nainokanoka and 20 (16.7\%) from Naiyobi.

When longevity measured, the respondents revealed to have lived in the area were $41(34.2 \%)$ for period between 21 and 25 years, 30 (25\%) for period between 16 and 20 years, $20(16.7 \%)$ for period between 11 and 15 years, $13(10.8 \%)$ for period between 5 and 15 years. It was only $16(13.3 \%)$ respondents who had stayed in the conservation area for less than 5 years.
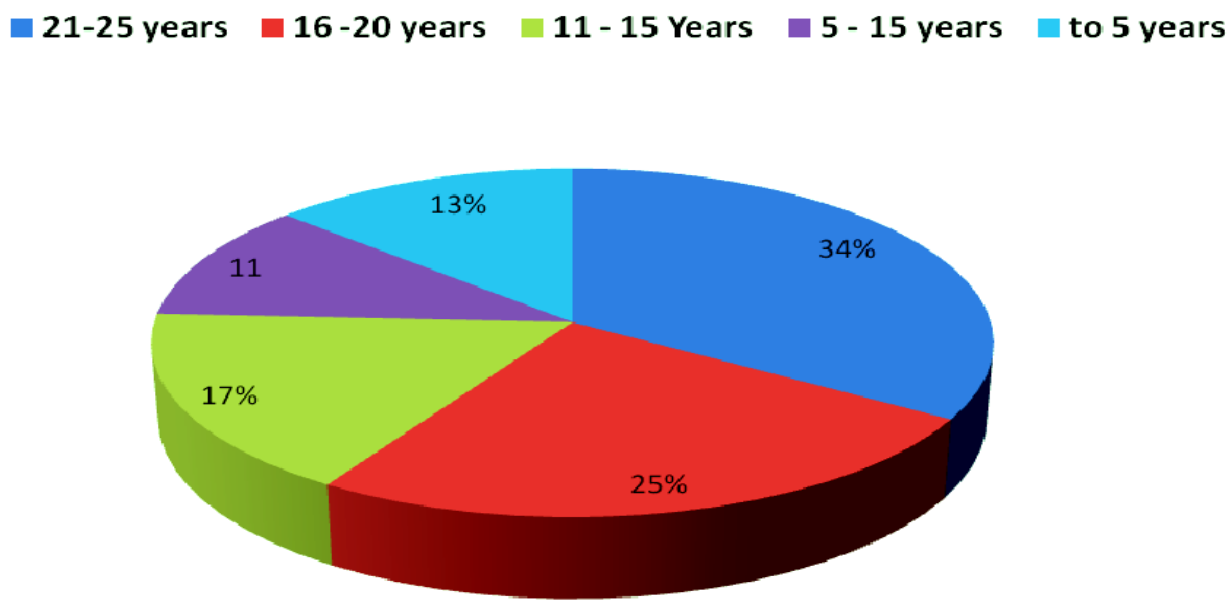

Figure 3. Time stay in the Conservation Area $(n=120)$

Community involvement in small scale business activities related to tourism considered to be the source of income to individuals who stays within the NCA and that is independent variable. The respondents when asked the percentage of relationship between tourism and social economic activities as independent variable, only $13.3 \%$ responded to consider small scale business as part of their economic support. All age levels except children's were involved in small scale businesses in their respective wards.

When the relationships on employment were measured, the findings revealed that community members have partnership in tourism companies as presented in the conceptual framework. The independent variable including involvement in small scale businesses, membership in tourism project, association or council, owners/partnerships in any tour company, revealed to have contributed significantly to the welfare of the community in the NCA. Nevertheless, it is also realized that intervening variable was a factors against the achievement of communities' welfare. Those factors include consumerist culture among community members, institutional arrangements between NPC and NCAA and NCA policy framework. When the data tested by using $K^{2}$ revealed that, there was significant difference between four wards $\left(\chi^{2}=7.75, \mathrm{df}=1, p\right.$ $<0.05$ ) when responded to how they were involved in tourism allied to independent variables. 
Among the activities of the community members, guiding the tourists and working in traditional Cultural Bomas findings revealed that most of the communities were direct involvement in tourism activities and that were allied to dependant variables.

From the facts stipulated above it was highly rated that tourism has a closely relationship with the changes of the communities social economic aspects.

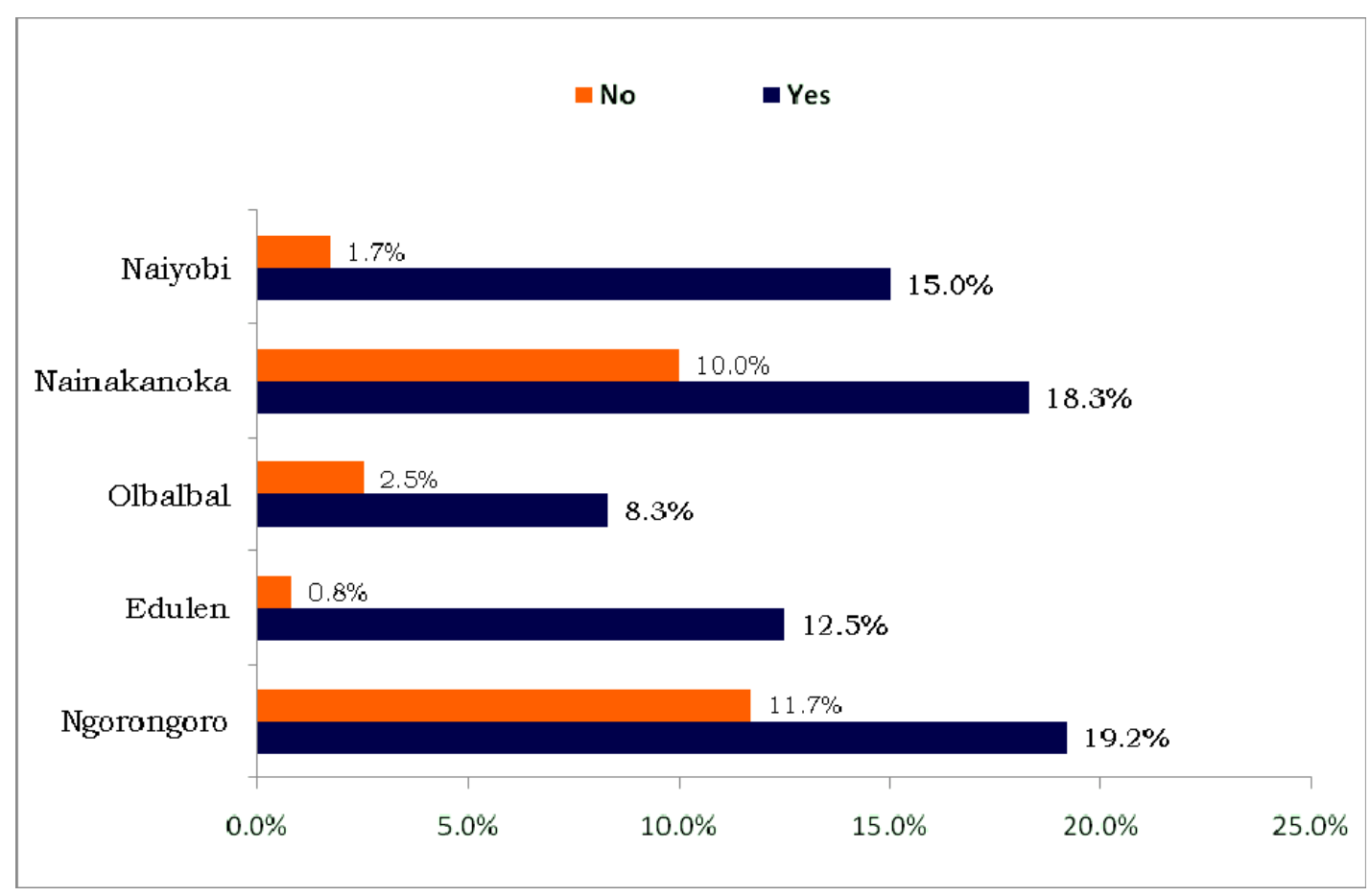

Figure 4. The Tourism and Socio-economic relationships $(\mathrm{n}=120)$

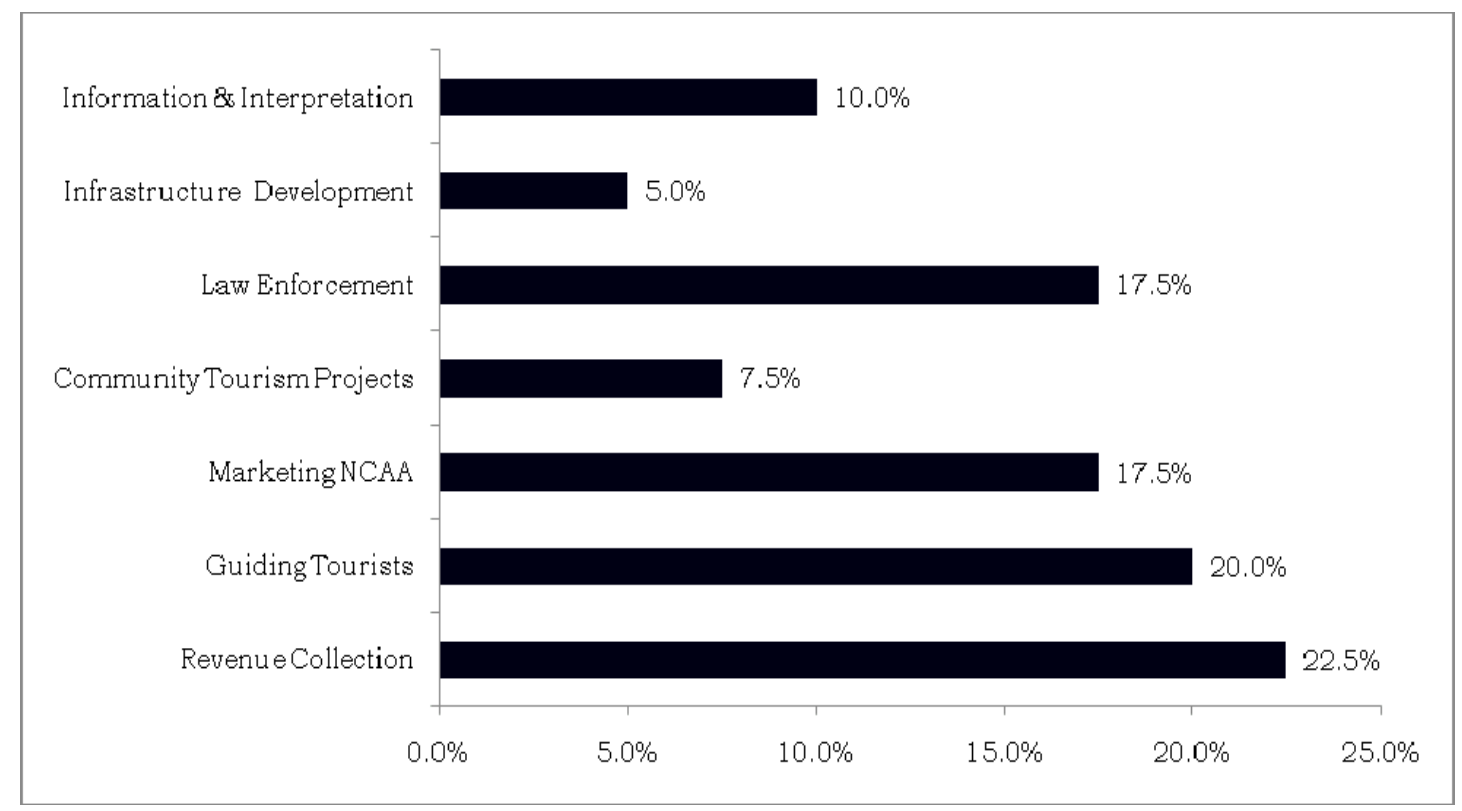

Figure 5. Community participation into different tourism activities in the NCA $(n=120)$ 
Furthermore, the findings revealed that all Wards responded and agreed that there is a strong relationship between tourism and socio-economic aspects of the communities in the NCA (Ngorongoro Ward 25.2\%, Endulen 19.3\%, Olbalbal 17.2\%, Nainokanoka 18.3\% and Naiyobi 20\%). Therefore, most of the community members agreed to have participated in different tourism activities. All the respondents from the community revealed that they were involved in tourism revenue collections in different seasons in their wards (22.5\%), guiding of the tourists (20\%), Marketing the NCA resources to different users (17.5\%), involvement into the communities tourism projects $(7.5 \%)$, law enforcement $(17.5 \%)$, infrastructure developments (5\%) and information and interpretations (10\%). Food security was mentioned to be the most important aspect of the Maasai community.

There were no significant difference $\left(\chi^{2}=33.138, \mathrm{df}=1, p<0.005\right)$ when communities responded on the tourism revenue assistance on food security. The response on tourism revenue support to food security was $89(76.7 \%)$ responded high and $27(23.3 \%)$ responded medium. There were no responses to low support of tourism revenue on food security. Responses were also relatively high to other social activities of Education, Medical services and livestock keeping of the community. This revealed high relationship of tourism and other socio-economic aspects.

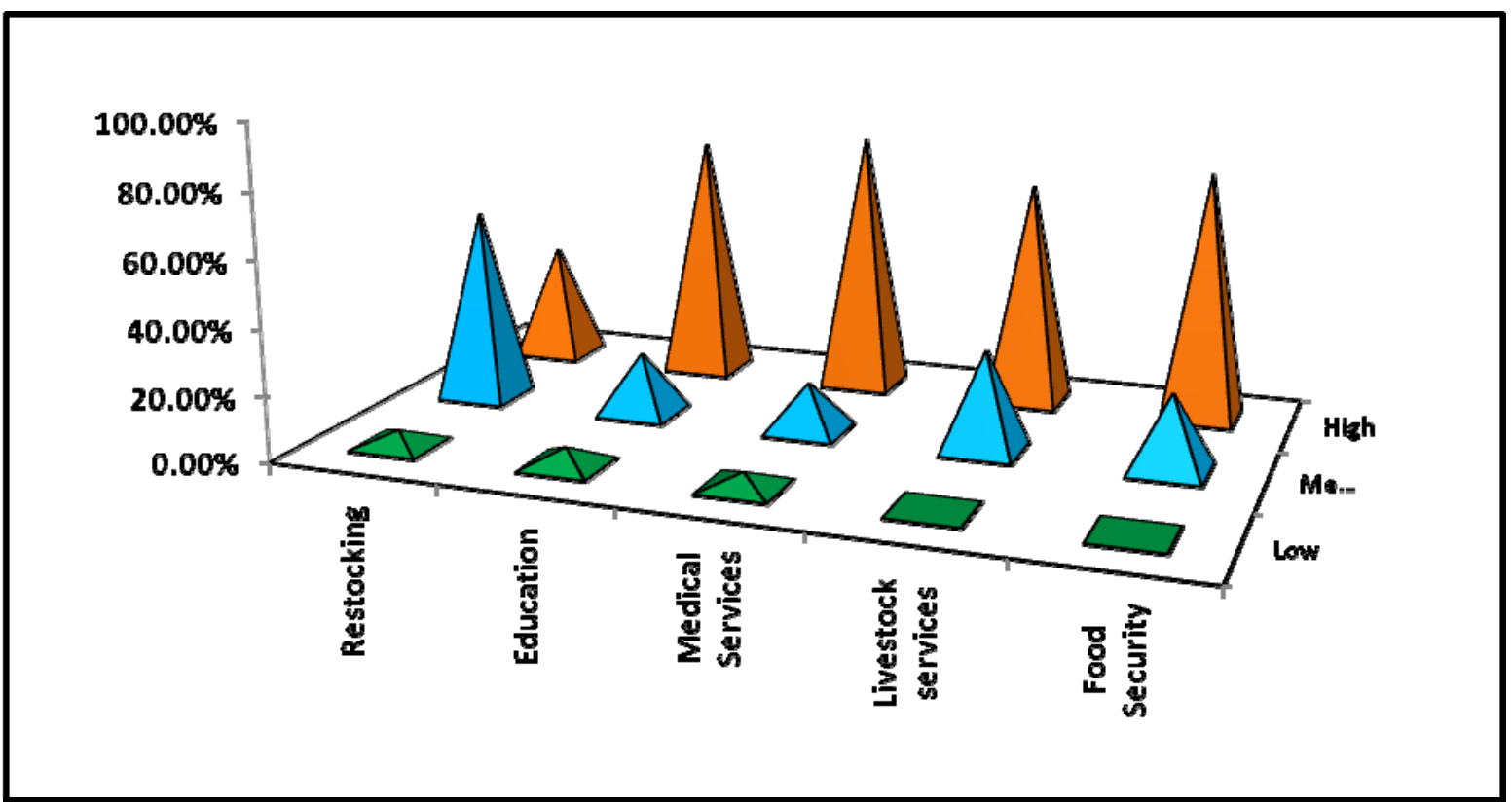

Figure 6. Tourism relationship (\%) to the communities' socio-economic aspects

The relationship was further realised being strengthened by the test of the data, that revealed to have no significant difference $\left(\chi^{2}=90.445, \mathrm{df}=3, p<0.005\right)$ when wards responses were compared. The response on provision of close supervision to communities tourism projects was $70(58.8 \%)$ from wards and $13(40.6 \%)$ from Communities. Also suggested to involve communities from the low level (sub villages) 40(29.4\%) wards and 9(28.1\%) PC, involve 
more village council 34(28.9\%) wards and 4(12.5\%) other communities of Datoga and provide information materials $9(7.9 \%)$ from Wards and 6(18.8\%) from Communities/PC. It was further suggested by the Communities that the tourism projects in their area needs very close supervision of their designed tourism projects to avoid leakages and maximize the aspired benefits.

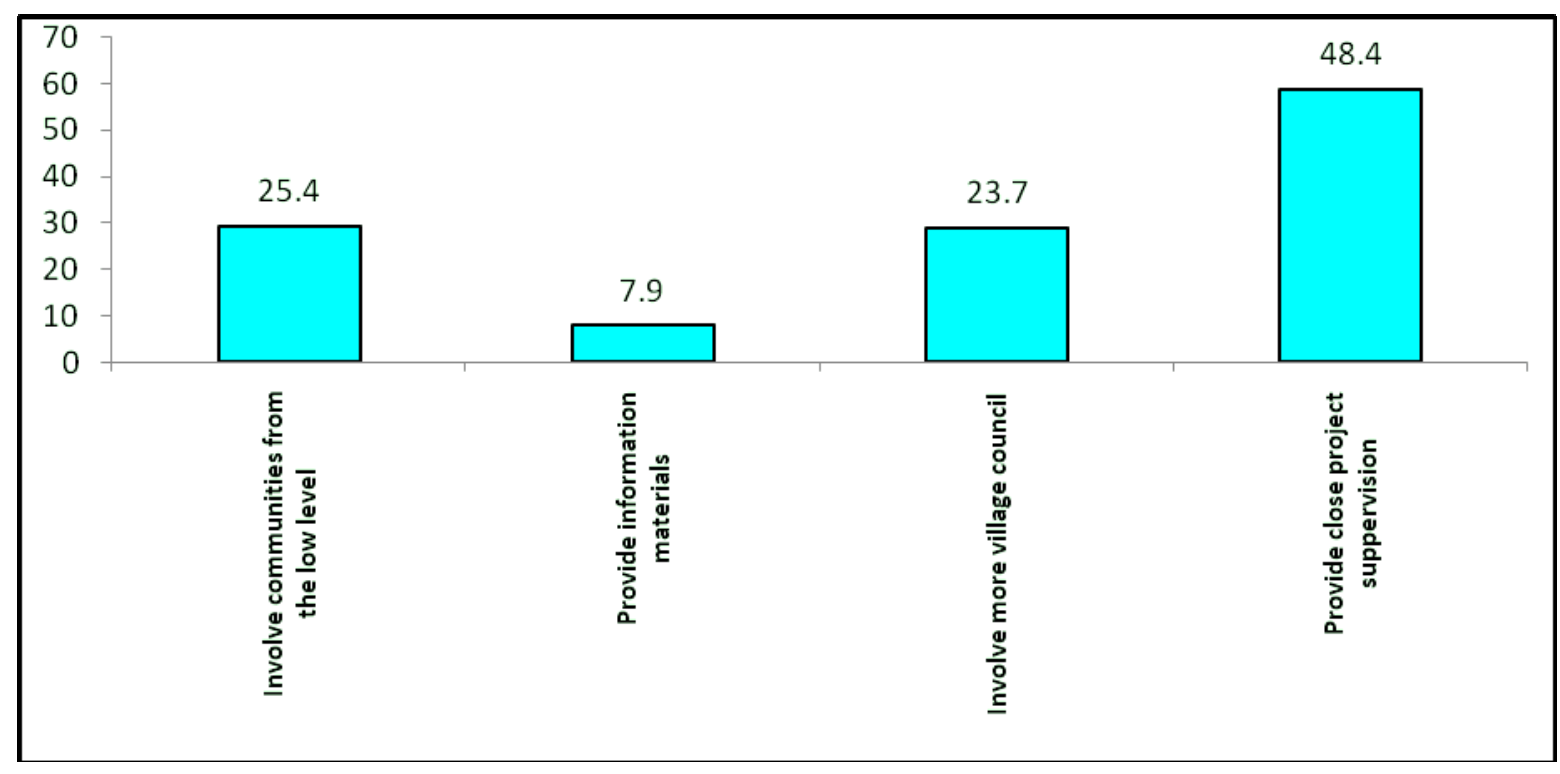

Figure 7. Improvement of the present communities' tourism activities structures

The interviews suggested that the improved tourism projects supervision would increase the revenues to the community. Strategies to reduce the Leakage of revenue that is caused by the Tour driver guides at the cultural Boma, if will be managed better then can improve the revenue and therefore, increase the shares of the communities. The current entry fees to the cultural Boma is USD 20, 000\$ which is equally to Tshs $32,000 /=$ at a rate of $1: 1600$. However the driver tours have converted to only Tshs $20,000 /$ per vehicle and the boma looses about Tshs 12,000/= per each entering vehicle. This has been persisting and it is now a price accepted to date. Nevertheless, some of the tour drivers do negotiation to pay less amount to almost Tshs 5,000/ which is USD 3.13\$ per vehicle. The supervision is really needed at the Cultural Boma's project.

\section{Discussion}

\subsection{The Socio-Economic Change in the NCA}

Economically the NCA resident depends much on livestock keeping as their basic economic activity (Melita, 2009). However the changes for the tourism dependence emerged as per decline of the livestock population among the society (Melita \& Mendlinger, 2013). The livestock keeping started declining in 1977 (Makacha et al., 1986; Kurji, 1981; Arhem, 1981a) and this increased the thoughts that tourism can be the best alternative to complement the 
declining economy of the residents in the NCA. The involvement of the communities in tourism was further strengthened in 2004 when they were fully involved in tourism activities. Melubo (2007), Runyoro (2006) and Melita (2009) reported that together with cultural boma (traditional villages) involvement in walking safaris and campsite management within the NCA, employment by tourism related agencies within the area including hotels and tour operators added value to relationship between tourism and socio-economic of the area.

Basing on the collected and analysed data, the activity like cultural boma (cultural village) contributed some reasonable amount of money that was directly shared by the communities within the NCA. A table presented below is showing the revenue collected from tourism and shared by the community from 2010 to 2013 .

Table 1. Revenue collected from tourism and shared by the community in the nca 2010-2013

\begin{tabular}{|l|l|l|l|}
\hline \multicolumn{2}{|l|}{ CULTURAL BOMA REVENUE FROM 2010-2013 } \\
YEAR & Tshs & EQUVALENT USD \$ & $\begin{array}{l}\text { EXCHANGE } \\
\text { RATE }\end{array}$ \\
\hline 2010 & $150,780,000$ & 100,000 & $1 / 1580$ \\
\hline 2011 & $159,540,000$ & 110,000 & $1 / 1590$ \\
\hline 2012 & $335,484,000$ & 210,000 & $1 / 1600$ \\
\hline 2013 & $158,970,000$ & 99,400 & $1 / 1600$ \\
\hline WALKING SAFARI REVENUE FROM 2010-2013 \\
\hline \\
YEAR & Tshs & EQUVALENT USD \$ & EXCHANGE \\
\hline 2010 & $78,066,432.05$ & $56,404.28$ & $1 / 383.50$ \\
\hline 2011 & $163,895,225.00$ & $107,472.00$ & $1 / 1525$ \\
\hline 2012 & $402,520,800.00$ & $256,219.47$ & $1 / 1595$ \\
\hline 2013 & $435,269,350.00$ & $272,043.34$ & $1 / 1600$ \\
\hline
\end{tabular}

These amounts in the table above "Walking Safari revenue" was a share between the NCAA and Community as agreed to have $50 \%$ shares to each from the walking safaris and camping in the shared campsites (NCAA/Community) within the Ngorongoro Conservation area.

These potential amounts of money can justify the relationships between tourism and socioeconomic activities within the NCA. This relationship is realised by looking on tourism development, economic and social innovation on the "positive" influence of tourism on the aspects relating to the quality of life of the local population. That relation seems to be fairly clear, since the increase of infrastructure facilities, equipment and services and the re-adaptation of physical spaces for tourism purposes (rehabilitation of the historical and artistic, environmental and ethnic-folklorist heritage), initially intended for tourist arrivals, and is turned to the advantage to the resident communities' too. The tourism impact in global context is high relatively as it touches the interest of many people and changes can be 
measured economically, socially as well as politically respectively. The improvement of infrastructures, changes over the standards of life and expansion of the other related activities in tourism areas is highly recognised as good relationship of the tourism and socio-economic. Mbaiwa (2003) defined the relationship between the two and explain that tourism is to have a major influence on the economy of a country or a particular region, and it should have strong linkages with the rest of the domestic economy and by having that influence it should be a catalyst for national and regional development, bringing employment, exchange earnings, balance of payments advantages and important infrastructure developments benefiting locals and visitors alike.

Ideally, the involvement of Local communities in tourism activities was to complement the conservation of natural resources. But when the communities go involved gave the priorities to tourism as the major source of income, employment opportunities and social interaction between the two (Mbaiwa, 2002). The Ngorongoro Conservation Area society commented that, tourism has been a major communities' rescue, however, the money collected are not all being shared by themselves. Few people benefits tourism of the area more especially the community leaders. Nevertheless, they revealed that some of the direct managed tourism projects are performing poorly because of supervision and management by the community staffs that have no enough skill to supervise the designed projects (Melita, 2009; Melita \& Mendlinger, 2013; Runyoro et al., 1996).

Tourism and the socio-economic relationship can be extended to the environmental conservation aspects basing on the organs related to the idea that is convincing the society while counting for the future development. These organs categorised in three groups of the stakeholders such Economists, Private (Business group), Conservationists and the Communities. Ashley (2000) commented that the economists generally see tourism as route to macro-economic growth, and particularly a means of generating foreign exchange; while the private (business group) see the tourism as a commercial activity, so the main concerns are product development, competitiveness and commercial returns. Many conservationists sees tourism as a form of sustainable use of wild resources, and hence as a way to enhance incentives for conservation and the rural people (communities) while with the support of the development and the NGOs sees tourism as one component of rural development. This can be a strong combination where a relationship between tourism and socio-economic activities are properly interacted. 


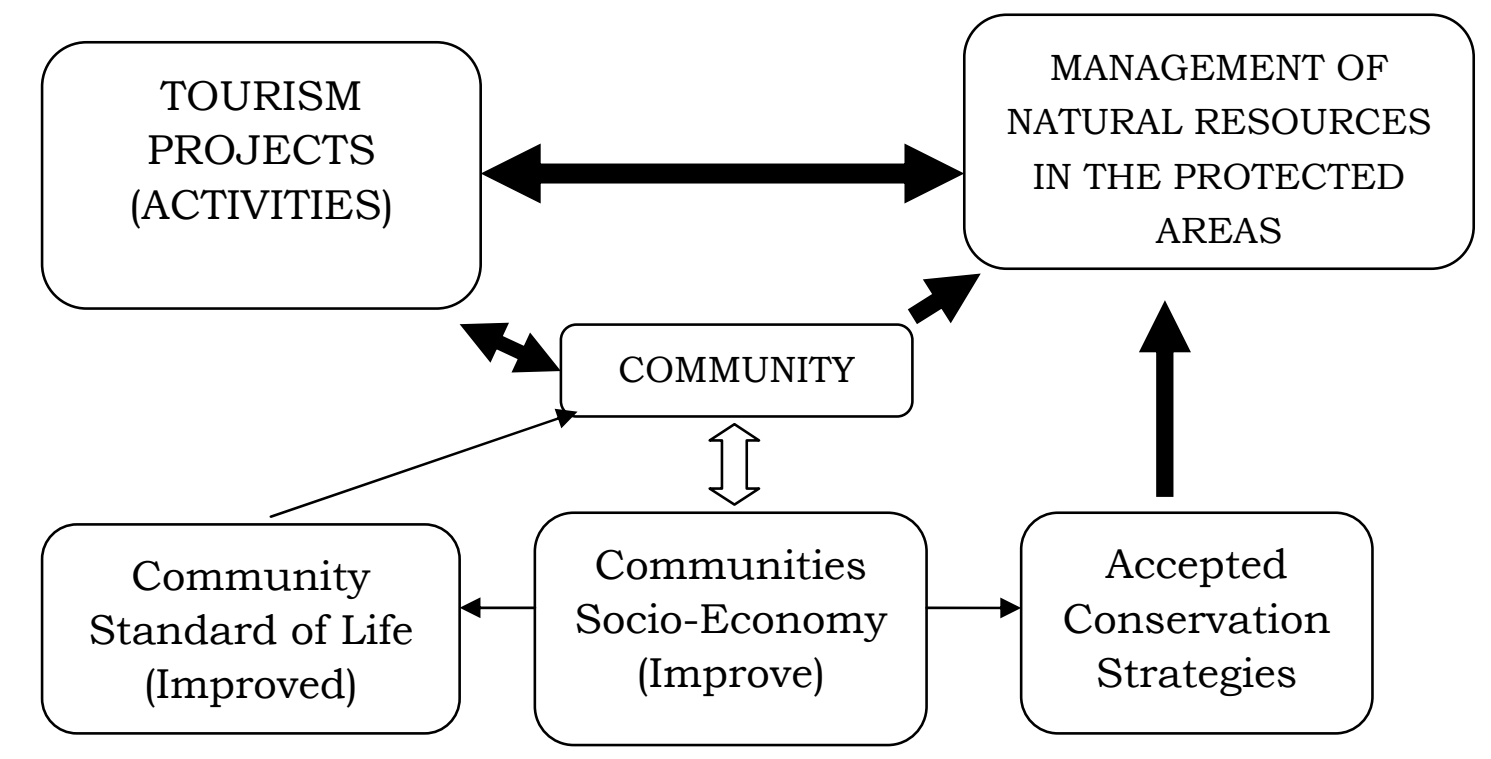

Figure 8. Tourism and Socio-Economic relationship for strong Conservation of protected areas

Source: Melita, 2014

\subsection{The Importance of Tourism in the Conservation Participations}

Tourism being a major basement of economics and contribution to GDP it interacts the major four societies of the Economists, Private (business community), Conservationists and the community, and has tailor made the change of environmental and natural resources use in the rural areas. This is a component where the socio-economy concerned is given a link. Performances of tourism activities have to cut across all four major categories and that has an impact on the economics of each group.

Basing on those facts the Government of Tanzania and tourism performances is basically rely on natural resources and sceneries attractions where the tourism relationships with economic of the communities basing the lands on the rural areas is interacted. As the matter of facts, it is important that the communities should benefit direct from tourism activities that they are involved and participated. However, because of the capabilities and understandings, the tourism activities have been dominated by the foreigners, those that have declined the ownership of the land by the communities. The act of dominance by the foreigners should be clearly scrutinized by the authorities as it has declined communities' ownership (Mbaiwa, 2002; Glasson et al., 1995).

The communities in the Ngorongoro Conservation Area started showing the interest in tourism in 2002 and get fully involved from 2004. The involvement was initiated through the campsites management whereby the NCA authority was devoted to organise all the tourism activities and the ground logistics especially in the campsites could be done by the communities. The share of revenue planned and agreed to be divided at $50 \%$ to each (Melita, 
2009). When the communities' directly involvement in tourism activities strengthened the conservation status of the Ngorongoro and most of the declined natural resources were recovered. Apart from the communities local economy (Melita \& Mendlinger, 2013) tourism plays a major role in the communities' economic recovery and restocking of the livestock took place among the community members. This study revealed that most of the family members whom went to participate in the cultural Bomas operations benefited and they went back into their respective villages to join their family members with few stocks to add to the family heads. However, the response for restocking was 40 (36\%) high, 66 (59.5\%) medium and $5(4.5 \%)$ low. That means if tourism will be handled properly in the rural areas can and will be the major route to poverty alleviation and millennia goals as it is set by the government Tanzania.

It is a matter of facts that what communities' gains from Tourism cannot compensate the loose of their land. However, rather than nothing better gain little. Villagers at Endulen Ward claimed that, the tourism gain contributes little to their development but agreed that a little gain has stabilized their social economy activities and restocking of the livestock which is their basic economic activity in the society. This had a proof from findings analysis that revealed tourism revenue supports livestock (92 (80.7\%) high, 17 (14.9\%) medium and 5 (4.4\%) low). In that context, communities in Ngorongoro supports the conservation strategies taking into consideration that it is a backbone of Tourism performance of all the protected areas. Those believe supported by other studies that revealed similarly situation including Kideghesho (2006); Baldus et al. (2004) and Emerton et al. (2001) where a major concern were little gained by the communities, but appreciation of economic changes in communities social lives and conservation perceptions.

\subsection{Tourism Impacts on the Society in the NCA}

The discussed relationship of tourism and socio- economy concepts is related to several other studies that found the relationship to have impacts in the communities Land, Infrastructures developments, social interactions, Employment, Conservation of nature and political status. It is clear that communities in the rural areas depend on the natural resources that are found there. However, there has been a tension over the utilization of the Natural resources where tourism is basically set its reliance. Tanzania tourism is basically set on natural resources available. About $27 \%$ of her territorial land has been dedicated for protected natural resources area. If the natural resource in Tanzania declines highly, tourism which complements communities' economy and raise awareness on conservation aspects will decline as well. The tourism decline will affect the community stances on conservation strategies and assume little advantage on conserving natural resources around them. Sherly et al. (1999) commented that the fundamental functions of ecotourism are protection of natural areas, production of revenue, education and local participation and capacity building. There are impacts accounted for each relationship mentioned above concepts and are explained below:

\section{- Impact on Land and its ownership.}

Generally the impact on Land use and ownership in Tanzania started when the natural resources land reclaimed from the village territories for conservation. The rights of natural 
resources use in the Ngorongoro Conservation Area are regulated by the law Act no 284 (Revised, 2002) and has marginalized the communities from their regular natural resources use. Due to that law, then the Villages land act of 1999 and the District Land Act of 1999 could not be applied over the NCA and that limits the land ownership by the Community.

Basing on the GMP 2006-2016 (Revised I 2010) and the area land use plans in 2006, the NCAA had areas identified for the hotel properties investment development. These sites raised the interests between the stakeholders in the NCA and created conflicts. As a conflict of interests, when tourism investment started within those sites in the NCA, the communities resisted the investments and claim to be denied some of the rights on the lands ownership. As results the investments in Nainokanoka, Endulen (Ndutu) and Olbalbal had been resisted on establishments since 2005 to date. However, communities claimed the resistance to be for only involvements and recognitions on their territorial land. These investments was argued by the Ngorongoro communities as a suffering a loss of sense of places when their surroundings transformed to accommodate the tourism industry requirements of a foreign-dominated companies. The tourism industry considering its development must note the sustainable development on the village lands as the major concept for equal access and opportunities to all stakeholders. Land use issues should not be the concern because when the communities benefits, satisfied and realise the advantage of tourism; regardless the loose of their lands they will accept tourism investments. Nevertheless, purely commercial grounds related to revenue generation in Ngorongoro, livestock is easily the most important form of land use communities accept and involved into. Tourism as a complement to livestock keeping activities should have a clear integrations when being conducted within the Ngorongoro to avoid land use conflicts and decline of the natural resources.

\section{- Infrastructures developments impacts}

The infrastructure status in the Ngorongoro Conservation Area started changing in 2000's, when a demand for the Lodges and new road identified as a need by the stakeholders.

The most noted changes of tourism were accommodations investments in the area. Most of the tour operators at present are demanding accommodation investment sites in the area of NCA and they diverted the interest to Campsites setups and development of the 2004. There is an increase of the Luxury camp sites that its demands has overtook the accommodations in the Lodge and Hotels and demand more areas for the establishments. That increases of demand necessitated the NCA to identify more areas for the Tented Lodges and Hotels investment within the area. This had a lot of reactions from the communities as has taken the land they were using from their villages. However, the communities by the law have no rights over the land ownership but demands over involvement to respect their interests. The investor's interest seems to overpower the communities' interest where the attention on the tourism development is emphasized by the NCAA. Purpura et al. (2009) urged that a great attention should also be paid to the "natural" fluctuations of tourism demand which isolatable by its own nature and very elastic to the changes in tourist products' prices, to the influence of trends and to a wide range of external factors. Tourism relationship to the socio- economic 
aspects of the communities at this juncture is related to the land use and the communities' social welfare and livelihood changes.

The roads network increased in the area of NCA when the development increased and the expansion of the sub villages within the area. Tourism routes were added to the Network when the walking trails were expanded to meet the demand in 2007. The GMP 2006-16 (Revised, 2010) categorized these roads into classes and these were Class I that included Lodoare to Serengeti Boundary (Golini) $(86 \mathrm{~km})$ and the Oldupai Museum access $(5 \mathrm{Km})$. The roads Class II were the Ngorongoro to Kakesio $(76 \mathrm{Km})$, View Point to Empakaai Crater (Fosbrooke Road) $(78 \mathrm{Km})$ and the Crater main roads (including ascent and descent) $(83 \mathrm{~km})$. The roads class II (Upgraded) included Empakaai to Kapenjiro (7 Km), Endulen to Olpiro (9 $\mathrm{Km})$ and the Empakaai to Naiyobi road $(11 \mathrm{Km})$. The Class III roads were Crater tracks (100 $\mathrm{km})$, Olbalbal from Main Road $(20 \mathrm{Km})$, Ndutu from Main Road $(25 \mathrm{Km})$ and All other tracks and walking trails including a track to Loliondo $(800 \mathrm{Km})$. These classes were classified according to the usability and the width of the road.

The road maintenance resources in the NCA have been a problem since the quarrel pits that were used since 1960s and 1970s are prohibited for further use. The other quarrel pits which identified for use have no quality gravels for the maintenance of the road. Apart from that, the need for more gravels it is expected to increase when other road tracks will change to major NCA roads. Currently the NCA needs about $66,048 \mathrm{~m}^{3}$ of gravels to repair about $1280 \mathrm{~km}$ road net work.

Nevertheless; roads the development link to the rural areas within the NCA. To counts for the relationships, the social economic changes as supported by tourism revenue changed the life style, standards and economic activities of the community. It is as well support the business setup to small scale business development within the NCA (Melita, 2009; Melita \& Mendlinger, 2013; Mbaiwa, 2002).

\section{- Social interactions and life style impacts}

Tourism revenue is trustworthy to convince the communities to accept conservation strategies in most of protected areas of Africa. That trust is basically accepted because tourism in most of the African countries depends on the charismatic animal numbers. Therefore, whole the convincing strategies of using tourism revenue to lure the interest of the community create a relationship that is directly applied to the social economic of the communities.

Most of the community members have benefited from tourism in their social life and economic aspects in various ways. Mostly the benefits are counted in terms of empowerments to the communities (Scheyvens, 1999). These empowerments (Scheyvens, 1999) are i.e. Economic empowerment which targets formal and informal empowerment as well as employment opportunities; Psychological empowerment which involves torching the interest of the communities' culture, norms and increase the confidence and trust-ships; Social empowerment where the local communities equilibrium touched, therefore Community cohesion is improved and allow the individuals and families work together to build a 
successful ecotourism venture. Also Political empowerment is counted in that relationship and stated that villager's opinion is important during initiations of any tourism project.

Some studies (Melubo, 2009) argued that, tourism has mostly negative impacts socially as prostitutions, intermarriages, culture dilutions, co modifications of communities norms, change of economic bases (Melita, 2009; Melita \& Mendlinger, 2013; Runyoro, 2007) and dependence on revenue directed to the communities. However, the communities' concepts are on those impacts and that is where the relationship between tourism and social economic based.

\section{- Employment opportunities and exposure impact}

When Scheyvens (1999), was discussing the empowerment revelled that employment is one of the potential aspect that community benefits from Tourism. Nevertheless, the findings during this study revealed that employment is one of the opportunities to gain from tourism but reported to have an impact on the communities' basic economic activities in Ngorongoro. About 169 young Maasai (Moran) are employed by the organisation and private investors and that was claimed by the family relatives to decline the manpower of the communities' in their villages. The arguments is basically based mostly on the time young men spend for other activities than livestock's keeping and that cause cows and small stocks poor handling and as a results the livestock has concentrated on the same places all the time for grazing and decline in numbers because of poor forage.

The increases of the communities population (87,851 people by 2013) in the NCA realized to have relation to the increasing of the tourism trend $(647,733-2013)$ in the NCA. The results of the population increases, has caused the NCAA to allocate more money to counteract the arising challenges including food security, education, health services, livestock services, road networks, reclaiming land for settlements and use of the natural resources (trees and thatching grasses for building). However it is proved that a relationship between tourism and socio-economic aspects of the communities is building strong contacts as observed in their simultaneously fast growing in the area. 


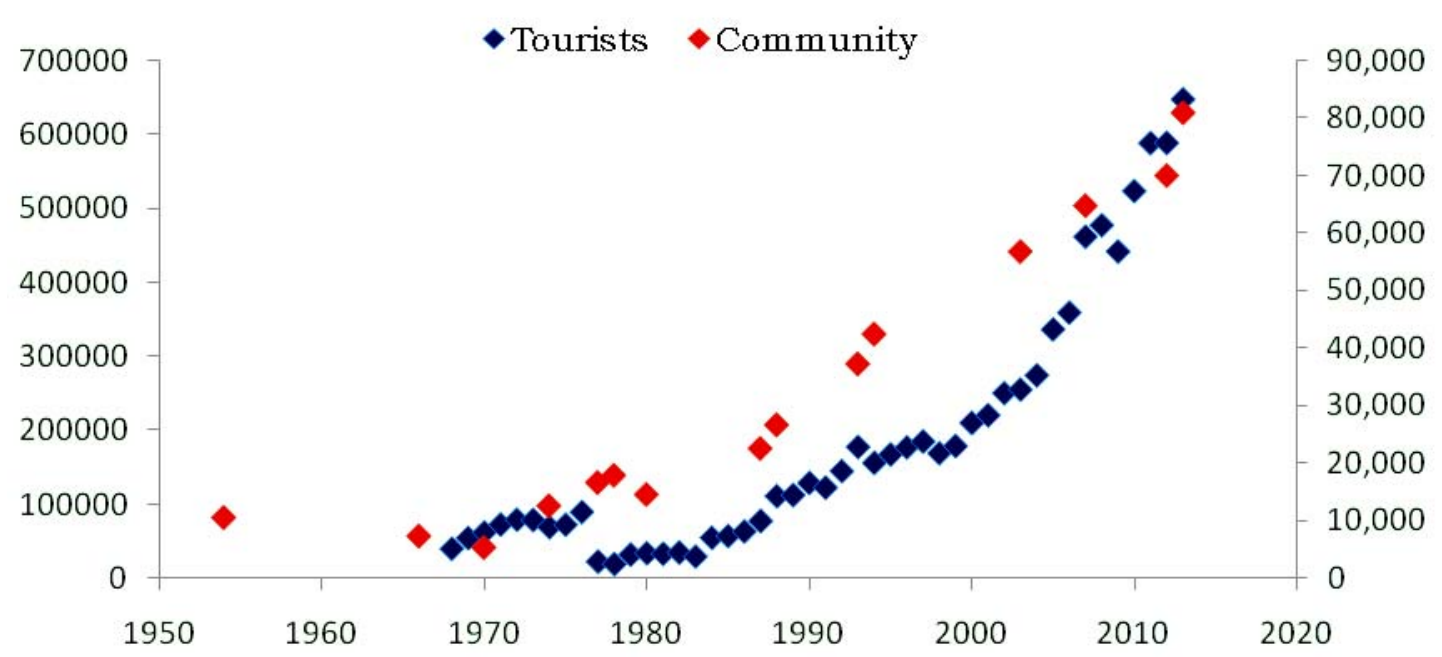

Figure 9. The increases relationship between tourism and community population in the NCA

Source: Melita, 2014

When employments of the NCA residents outside the NCA Authority measured it proved that there are about $23 \%$ of the supported students by the NCAA whom have been employed in different companies in the Country. However, when weighing the social relationship of the communities and the tourists, data revealed that most of the young Maasai are being married by the visitors (foreigners) and leave their villages to town and abroad. Therefore, this was also claimed by the family members that it takes away manpower and decline the primary economic set up which is livestock keeping.

The communities argued that tourism employment has changed the life style of the young Maasai and that has diluted the intact Maasai culture within the area (Melubo, 2007). Some of young people seem to have moved from the village to small nearest Towns and the relatives are missing their helps and supports. On the other hand, that could be positive impact on the conservation of the area and the strategies of reducing the human population within the area which is now about 87,851 people (NCAA Census, 2013).

\section{Summary and Recommendations}

Tourism and Socio-economic of the communities in the NCA are inseparable related activities; if consideration of the operations and administration of those activities will contemplate over all other economic factors. While the essence of poor understanding of the revenue from Tourism directed to the communities is high, the communities are appreciating tourism support to their local economy. However there is an argument from the respondents that it has changed the local communities' life and support to their basic local economy.

The communities value the Tourism when they realize the benefits that are directed to them and strengthen their economy. The realizations help the conservation strategies of the protected areas and the management. To build better the tourism and socio-economic relationships, the NCAA needs to maintain and strength the involvement of communities into 
tourism activities and let them realise the benefits and improve their social economy for the betterment of the conservation strategies of the area. It is true that not all the people realises the existing relationship between the two concepts because of little or poor understanding of how these two ideas interact when they count the profit directed to them. But from the study, I am assured that there is clear understanding of the relationship between Tourism activities and the socio-economic aspects of the area. The restocking of the livestock into the family heads is appreciated by many people in the NCA and since it is the communities' primary activity, it needs to be strong and gain its stability. However, it is clear that the primary economy is declining compare to the growing number of people within the Ngorongoro Conservation Area. This study confirmed that, Tourism activities are on the way replacing livestock economy as the time goes. The community social activities support has gains much from tourism revenues. The NCAA has supported a lot on food security to the community, livestock services, healthy services, education, employment and small scale businesses. This is where the real relationship between tourism and socio-economic activities based on.

The improved communities' economy has been attracting most of the other Maasai communities outside the NCA boundary and other ethnic groups of Hadzabe and Datoga to migrate into the area. As a result the communities' population has realised an increase of $4.9 \%$ per year. This will have an impact on operational costs by the NCAA to support the community services in the NCA. A clear way, procedures and criteria's to limit immigrants should be devised by the NCAA to solidify the tourism and socio-economic relationship to continue the coexistence of wildlife and community activities of the Ngorongoro.

\section{References}

Adams, K. M. (1984). Come to Tana Toraja, "Land of the Heavenly Kings": Travel agents as brokers in ethnicity. Annual paper on Tourism \& Research, 11, 469-85. http://dx.doi.org/10.1016/0160-7383(84)90032-X

Adams, K. M. (1995). Making-up the Toraja? The appropriation of tourism, anthropology, and museums for politics in upland Sulawesi, Indonesia. Journal of Ethnology, 34, 143-54. http://dx.doi.org/10.2307/3774103

Akama, J. S., \& Kieti, D. M. (2003). Measuring tourist satisfaction with Kenya's wildlife safari: a case study of Tsavo West National Park. Tourism Management, 24, 73-81. http://dx.doi.org/10.1016/S0261-5177(02)00044-4

Beh, A., \& Bruyere, B. L. (2007). Segmentation by visitor motivation in three Kenyan national reserves. Tourism Management, 28, 1464-1471. http://dx.doi.org/10.1016/j.tourman.2007.01.010

Bendix. (1989). Tourism and cultural displays: Inventing traditions for whom? Journal of Am. Folk, 102, 131-46. http://dx.doi.org/10.2307/540676

Bookbinder, M. P., Dinerstein, E., Rijal, A., Cauley, H., \& Rajouria, A. (1998). Ecotourism's support. Journal of biodiversity conservation, 12, 1399-404. 
Bruner \& Kirshenblatt-Gimblett. (1994). Maasai on the lawn: tourist realism in East Africa. $\begin{array}{lllll}\text { Journal of Cultural } & \text { Anthropology, } & \text { 9, }\end{array}$ http://dx.doi.org/10.1525/can.1994.9.4.02a00010

Bruner. (1987). Of cannibals, tourists, and ethnographers. Journal of Cultural Anthropology, 4, 438-45. http://dx.doi.org/10.1525/can.1989.4.4.02a00070

Epler-Wood, M. (1998). Meeting the Global Challenge of Community Participation in Ecotourism: Case Studies and Lessons from Ecuador. Work. Pap. No. 2. Washington, DC: Am. Verde, Lat. Am./Carib. Div., USAID/TNC.

Gamper, J. (1981). Tourism in Austria: a case study of the influence of tourism on ethnic relations. Ann. Tour. Res., 8, 432-46. http://dx.doi.org/10.1016/0160-7383(81)90007-4

Glasson, J., Godfrey, K., \& Goodey, B. (1995). Towards Visitor Impact Management: Visitor Impacts, Carrying Capacity and Management Responses in Europe's Historic Towns and Cities. England: Avebury.

Kideghesho, J. (2006). Constraints in Implementing the Benefit- Based Approaches as a Strategy for Conserving Wildlife in Western Serengeti, Tanzania. Papers of the 11th Biennial Conference of the International Association for the Study of Common Property, Bali, 19-23 June 2006, pp. 78-92.

Kokel, M. (2007). Alleviating poverty through ecotourism programmes in Ngorongoro Conservation Area -Tanzania: prospects and challenges. University of Dar Es salaam.

Kurji, F. (1981) Human population trends within and around the Ngorongoro Conservation Area: The demographic settings. Bureau of Resource Assessment \& Land Use Planning, University of Dar es Salaam (Dar es Salaam) HB3662.9.N55 K87 1981 102-439-599 (Last edited on 2002/02/27 18:02:09 US/Mountain).

Leong, W. T. (1989). Culture and the state: manufacturing traditions for tourism. Critical Studies in Mass Communication, 6, 355-375. http://dx.doi.org/10.1080/15295038909366762

Lett, J. (1989). Epilogue. In V. Smith (Ed.), Hosts and Guests: An Anthropology of Tourism (pp. 275-79). Pittsburgh, PA: University of Pennsylvania Press.

Mansperger, M. C. (1995). Tourism and cultural change in small-scale societies. Humman Resources Management and Org., 54, 87-94.

Mbaiwa, J. E. (2002). The Socio-Economic and Environmental Impacts of Tourism in the Okavango Delta, Botswana. Harry Oppenheimer Okavango Research Centre, University of Botswana, Maun.

Mbaiwa, J. E. (2004). The Socio-Economic Benefits and Challenges of a Community- Based Safari Hunting Tourism in the Okavango Delta; Botswana. Journal of Tourism Studies, 15(2), $120-139$.

Melita, A. W. (2009). The Impact of tourism revenue to the local communities of Ngorongoro. M.Sc. thesis, University of Kent. 
Melita, A., \& Mendlinger, S. (2013). The impact of tourism revenue on the local communities' livelihood: A case study of Ngorongoro Conservation area, Tanzania. Journal of Service Science and Management, 6, 117-126. http://dx.doi.org/10.4236/jssm.2013.61012

Mvula, C. D. (2001). Fair Trade in Tourism to Protected Areas- A micro Case study of Wildlife Tourism to South Luangwa National Park Zambia. Int. J. Tou. Res., 3, 393-405. http://dx.doi.org/10.1002/jtr.349

Porpura, A., \& Vazquez, F. J. C. (2007). Relational tourism, development and social innovation. Journal of Rural Tourism.

Runyoro, A. V. (2006). Analysis of alternative livelihood strategies for the pastoralists of Ngorongoro Conservation Area, Tanzania. PhD. Thesis. Sokoine University of Agriculture, Morogoro, Tanzania.

Runyoro, V. A., \& Vedeld, P. O. (1996). Resources deprivation and economic differentiation among the Maasai of Ngorongoro Conservation Area, Tanzania. Discussion paper number d-20/1999. NLH Agriculture University of Norway.

Scheyvens, R. (1999). Case study: Ecotourism and the empowerment of Local communities. Tourism Management, 20. http://dx.doi.org/10.1016/S0261-5177(98)00069-7

Seiler-Baldinger, A. (1988). Tourism in the Upper Amazon and its effects on the indigenous population. In P. Rossel (Ed.), Tourism: Manufacturing the Exotic (pp. 177-93). Copenhagen: IWGIA.

Simpson, M. C. (2007). Community Benefit Tourism Initiatives-A Conceptual oxymoron?. Tourism Management, 29, 1-18. http://dx.doi.org/10.1016/j.tourman.2007.06.005

Stronza, A. (2001). Anthropology of Tourism: Forging New Ground for Ecotourism and Other Alternatives. Annu. Rev. Anthropol, 30, 261-83. Anthropological Sciences, Stanford University, Stanford, California 94305. http://dx.doi.org/10.1146/annurev.anthro.30.1.261

Urry, J. (1990). The Tourist Gaze: Leisure and Travel in Contemporary Societies. London: Sage.

Wunder, S. (1999). Promoting Forest Conservation through Ecotourism income? A Case Study from the Ecuadorian Amazon Region. Bogor, Indonesia: Centre of International Forestry Research.

\section{Copyright Disclaimer}

Copyright for this article is retained by the author(s), with first publication rights granted to the journal.

This is an open-access article distributed under the terms and conditions of the Creative Commons Attribution license (http://creativecommons.org/licenses/by/3.0/). 